\title{
THE IMPACT OF THE ARABIAN NIGHTS IN MODERN EGYPTIAN NARRATION: MAHFOUZ'S ARABIAN NIGHTS AND DAYS AS A CASE STUDY*
}

\author{
SHARIEF ELGAYYAR
}

\begin{abstract}
The Arabian Nights were passed orally for long eras, long before they were written down; the collective sense, through several anonymous narrators, developed them: changing, modifying, omitting and adding to this oral discourse. All for the purpose of entertaining the public according the spirit of the age and the socio-cultural contexts, afterwards, it was recorded in different versions, as diverse as their sources, up until the landmark version, namely the one printed in Bulak, Egypt in 1835. The West is to be commended on paying attention to the significance of The Arabian Nights, academically and creatively, before its original-home, especially since it was later translated to many languages. After French orientalist Antoine Galland (1646 - 1715) translated into French between 1704 and 1713 a third of the manuscript he had brought from the Orient.This study delves into "The Impact of The Arabian Nights on Modern Egyptian Narration". The researcher tries to point out how Egyptian writers were inspired by the classic text by examining Naguib Mahfouz's Arabian Nights and Days (Layālī alf laylah) as a case study. An analytic, text-based approach was used to detect the intertextual interaction between the classic and the modern, and to explore how classical elements and connotations were employed within the modern text.
\end{abstract}

Key words: Arabian Nights, Naguib Mahfouz, Arabian Nights and Days, Interaction, Intersexuality, Layālī alf laylah.

\section{Introduction}

The Arabian Nights were passed orally for long eras, long before they were written down; the collective sense, through several anonymous narrators, developed them: changing, modifying, omitting and adding to this oral discourse. All for the

* An Arabic version of this article was previously published at the cultural magazine of Jordan University المجلة الثقافية لجامعة الأردن in volume NO.79 , 2011. 
purpose of entertaining the public according the spirit of the age and the sociocultural contexts. Afterwards, it was recorded in different versions, as diverse as their sources, up until the landmark version (Al-Qalamawy 1943: 2),namely the one printed in Bulak, Egypt in 1835.

The origins of the tales in The Arabian Nights are probably, according to historical accounts, Persian and Indian, with Arab tales from Egypt and Baghdad added later on. Historian Abu al-hasan al-Mas 'ùdī (Died 957 AD/ 346 AH) in his Muruj adh-dhahab (The Meadows of Gold) supports what was later mentioned by Ibn al-Nadim (Died $1047 \mathrm{AD} / 438 \mathrm{AH}$ ) in his Fihrist that the origin of Shahrazad's tales is a Persian book titled "Hezar Afsan", which means a thousand myth. This book was translated into Arabic under the title "A Thousand Nights". Some scholars argued over this Persian origin, asserting that it is originally Indian, pointing out that Shahrazad's tale, functioning as a frame to the tales, supports their view. Later, they maintain, these Persian-Indian roots were supplemented with Arab tales from Baghdad and Egypt, among others.

French orientalist Antoine Galland (1646-1715) was the first to introduce The Arabian Nights to audiences outside the Middle East(Irwin 1994; Knipp 1974; Fahndrich 2000); he translated into French between 1704 and 1713 a third of the manuscript he had brought from the Orient (Abo Al-Hussein 1994: 268). This translation became popular since Galland formulated it to suit the European cultural standards in the $18^{\text {th }}$ century, when the Western cultural atmosphere was seeking some sort of 'cultural Otherness' in order to fight Classicism with Romanticism. Shahrazad's tales were romantic indeed, suitable for a Europe where women were generally prominent on the cultural scene. Galland dedicated his translation to the Marquise d'O, one of the consorts of the Duchess of Burgundy (Abo Al-Hussein 1994: 268), which contributed to the spread of The Arabian Nights, in addition to its oriental-themed romantic narration, filled with the strange and the exotic. This made the West eager to know these remote lands rich with art and natural resources.

The West is to be commended on paying attention to the significance of The Arabian Nights, academically and creatively, before its original-home, especially since it was later translated to many languages. Andre Gide summed up how Europe views Arabian Nights when he said that there are three world classics: the Holy Bible (the New and Old Testaments), Homer's epics (The Iliad and the Odyssey), and The Arabian Nights (Abo Al-Hussein 1994: 275-276). Hence, the West transformed Shahrazad's narrative into a text proper by collecting, translating, and researching it. On the other hand, it was overlooked in Arab literary circles up until the early $20^{\text {th }}$ century. Critical, academic studies of Arabian Nights started with Saheir al-Qalamawy in her Ph. D. thesis at Cairo University (then the Egyptian University) in 1939, which had the work's title and was supervised by Taha Hussein (Al-Musawi 2004: 351-352). The gates were consequently wide open for critical and creative appreciation of the classic text, which proved its resilience to such a plethora of critical and creative interpretations. 
This study delves into "The Impact of The Arabian Nights on Modern Egyptian Narration". The researcher tries to point out how Egyptian writers were inspired by the classic text by examining Naguib Mahfouz's Arabian Nights and Days as a case study. An analytic, text-based approach was used to detect the intertextual interaction between the classic and the modern, and to explore how classical elements and connotations were employed within the modern text.

\section{The Spectacles, the Mirror, and the Roots of Narrationin Mahfouz's Arabian Nights and Days}

Egyptian writer Naguib Mahfouz (December 1911 - August 2006) had quite a diverse creative career that witnessed the publication many novels, short stories, plays, and essays. In more than half a century, starting from the 1930s, he published more than 50 works, culminating in being awarded the Nobel Prize for Literature in 1988.

Readers of Mahfouz's literature, especially his novels, note that he has a philosophical, Sufi mind that works as magnifying spectacles, probing existence itself to find its secrets, trying to anticipate the future by examining the present from a philosophical viewpoint, one which combines Existentialism with a Sufi spirituality that aims at absolute faith or redemption. He notes the socio-political absurdity of the world around him. A graduate of the Department of Philosophy, Faculty of Arts, Cairo University (then the Egyptian University) in 1934, Mahfouz was interested in addressing taboos in his society, where socio-political flaws led to the absence of justice and freedom for long periods. Mahfouz himself says: "around us, life seems harsh. Our personal life sometimes seems absurd, that's exactly it: social-absurdity. So far, ever since we opened our eyes, we have been living a streak of internal frustrations. Whenever we breathe, someone comes to choke the air out of us and ruin our lives" (Al-Gheitany 1980: 54). He was driven to resist and subdue such absurdity by rationalizing and interpreting it in light of his existentialist, Sufi vision within a narrative of social realism. This is evident in his novels before and after the 1952 revolution, such as: Cairo Modern (1945), Khan Al-Khalili (1946), Midaq Alley (1947), The Beginning and the End (1949), Palace Walk (1956), The Palace of Desire (1957), Sugar Street (1957), The Thief and the Dogs (1961), among others.

In most of his works, Mahfouz maintains his social realism, even though he lived in an age when world literature did not address reality "but rather the self, the stream of consciousness, the subconscious, the supernatural. However, the society I was representing has not been portrayed realistically in the first place, so I could not use the modern literary techniques I was reading about back then" (Al-Gheitany 1980: 42). Later he used those narrative techniques in many of his novels, especially The Thief and the Dogs. 
Mahfouz could not have resisted such modern influences had he not been open to the intricate circles of world and Arab classics, had he not been able to absorb the literary and religious heritage in its different forms and sources, to interact with it, to be inspired by it, and to build intertextual connections to it. For example, he was inspired by Ancient Egyptian history: Khufu's Wisdom (1939), Rhadopis of Nubia (1943), and Thebes at War (1944). Furthermore, he drew from The Arabian Nights in his Arabian Nights and Days (written 1979, published 1982); the subject of the present study, as well as other works, such as: Children of the Alley (1959), Fountain and Tomb (1975), The Harafish (1977), and The Devil Preaches (1979). The latter is a short story collection; it includes a play with the same title, inspired by one of the tales in The Arabian Nights, namely "The City of Brass".

Mahfouz was not alone in drawing from the literary heritage, especially Arabian Nights. Many writers did the same, such as: Taha Hussein in Dreams of Shahrazad (1943), Tawfiq al-Hakim in Shahrazad (1934) and Bewitched Palace (co-authored by Al-Hakim and Hussein) (1936), Ali Ahmed Bakathir in The Secret of Shahrazad (n.d.), Alfred Farag in In the Company of Tabrizi and his follower Quffa (2003), Jabra Ibrahim Jabra and Abdul RahmanMunif in A World without Maps (1992), Badr al-Deeb in The Tale of Tawaddod (n. d.) and in A Renarration of Hasib and the Queen of Serpents (n. d.), Leana Badr in The Eye of the Mirror (2009), and finally HossamFakhr in Tales of the Other (2008).

When Mahfouz and others drew inspiration from the literary heritage, they contributed, one way or another, in establishing the roots of the Arabic narrative discourse, and situated the Oriental civilization's vision within the cultural ocean of civilization as a whole. Additionally, this dialogue between the modern and the classic has effectively and creatively led to the portrayal of the issues of everyday life, with the hope of changing harmful social and political beliefs. This is manifest in the subject of the present study: Mahfouz's Arabian Nights and Days, in which the writer interacts with Arabian Nights. He said that "The Arabian Nights has given me issues and motives to address, and hence came my Arabian Nights and Days" (Mahfouz 1994: 378).

\section{False Continuity in a different frame}

The narrative discourse of Mahfouz's Arabian Nights and Days has a familiar starting point, both for Arab and Western readers; the title of the novel is a direct allusion to The Arabian Nights, renowned in the Arab World and abroad. It represents a textual continuity, signifying the text's openness towards the multifaceted oral heritage deeply rooted in the Oriental civilization. This leads the reader into the adventure of unveiling the modern narrative world while being reminded of its roots. It is a contrast between the two texts in which the reader finds out the ability of the 
modern text to interact with the classic one and to implement the latter's formal and semantic elements in order to enrich itself and express the issues of its civilization.

However, this textual-interaction at the very beginning of Arabian nights and days soon turns into an artistic coupling, one based on choosing and altering relevant parts. Mahfouz's narrator drew inspiration from Arabian Nights; he quotes parts from it in different contexts with different participant roles. This way, such quotes become more suitable to Mahfouz's text and its openness to social, political, and even epistemological issues, whereas the original text does not include such issues. Mahfouz himself said: "I believe that in this novel I have expressed my major concerns by combining what can be called 'political realism' and 'metaphysical reflections' or 'Sufi reflections', if you will. The Arabian Nights was so adaptable that it allowed me to express this wide-ranging combination" (Mahfouz 1994: 380). What Mahfouz describes is clearly visible in the narrative discourse of his 'Nights'; political-absurdism is used to reveal conditions under authoritarian rule, the responsibility of the elite and the public, the limits of reason, and the role of religion in obtaining spiritual, Sufi redemption. His ultimate goal is social justice, which guarantees a fruitful life in this world and the next (Al-Zamarli 2002: 144).

Such a political, existentialist, Sufi vision had its clear effect of the aesthetics of Mahfouz's work, which includes 17 chapters: "Shahryar", "Shahrazad", "The Sheikh", "The Coffeehouse of Princes", "San'aan Al-Gamali", "Gamasa Al-Bolti", "Al-Hammal [the porter]", "Nur al-Din and DoniaZad", "The Adventures of Agar the Barber", "Anis Al-Jalis", "Qut Al-Qulub", "Aladdin Abo Al-Shamat", "The Sultan", "The Cap of Invisibility", "Ma'rouf the Cobbler", "Sindbad", and "The Weepers".

Notably, this discourse is similar to that of The Arabian Nights; its narrator is omniscient, the passive voice is predominantly used, and some characters are named after ones from the classic text. However, the overall frame and its semiotics are different. The character roles of Arabian Nights are changed in a way that suits the political nature of Mahfouz's text, which corroborates Boris Uspenskij assertion that: "We must emphasize the general semiotic importance of framing. In this context, the concept of the beginning and the end acquires a special purpose, and its importance lies in shaping the cultural systems we believe to be representative and the ones with a semiotic vision of the world (or more precisely: systems that reveal a personal and social experience)" (Uspenskij 1999: 149).

Mahfouz's text starts from the frame of Arabian Nights, though in reverse; his narrator returns the textual power and narrative authority to the man/Shahryar, thus reaffirming the return of patriarchal domination of men over both the cultural situation portrayed by Arabian Nights and Days and the narrative itself. Consequently, the man is the center of fiction and the socio-political aspects of the real world. At the start of Arabian Nights and Days, which also represents the end of The Arabian Nights, the man / authority / Shahryar, declares that Shahrazad, after three years of 
fear and hope, is finally pardoned. He says to his Vizier "Dandan" in a moment of reluctant hope: "After the Fajr [dawn] prayer, while dark clouds stand steadfast against the lively stream of light... it is my royal will that Shahrazad shall become my wife" (Mahfouz 1982: 3-4). Justifying his decision, he said that her tales has made him quite reflective, and that she had gave him a son.

A closer look at this pardon reveals that it is issued with skepticism. The king/ authority/ Shahryar pardoned Shahrazad/ women in what can be considered a new age/ dawn, though the darkness within him remains steadfast. That's why Mahfouz's Shahrazad is miserable despite being pardoned. She doubts that Shahryar has understood the moral of her tale, since "a crime remains a crime no matter what... how many virgins has he killed, how many pious men has he murdered, there is no one left in the kingdom but hypocrites" (Mahfouz 1982: 6). Shahrazad's position here indicates how little her role is in trying to reform the king. This is different from the pardon in the classic text, where Shahryar/ the man declares Shahrazad/ the woman victorious "By Allah, O Scheherazade, I pardoned thee before the coming of these children, for that I found thee chaste, pure, ingenuous, and pious ... I take the Almighty to witness against me that I exempt thee from aught that can harm thee" (The Arabian Nights and Days; Al-Hilal: 135).Then Shahryar ruled his kingdom justly for two more decades (The Arabian Nights; Breslau 2003: 6).

Therefore, it is noteworthy that Shahrazad's role in Mahfouz's 'Nights' does not exceed making remarks on Shahryar and his corruption. Even her tales, one of the main reasons behind Shahryar's pardon of her and all women, is not attributed to her own wide knowledge, as it was in The Arabian Nights, but rather to her mentor (and the mentor of many others, both old and young), the grand Sheikh Abdullah alBalkhi. "The novel does not portray al-Balkhi as a source of mystic knowledge, which is a valid source in Sufism, but as a Qutb (axis) around whom the whole world revolves" (Hafez 1994: 35). Shahrazad, with all her vast knowledge demonstrated in TheArabian Nights, is just one of his many apprentices. He is the source of worldly and divine knowledge, a personification of social and spiritual values in Mahfouz's Nights. This bewilders the physician Abdel Qader al-Mahini, the Sheikh's friend and the symbol of rational thinking in the novel, who says to the Sheikh: "all mouths are praying for Shahrazad, while all the merit is yours... if she had not been your apprentice, she wouldn't have become the Shahrazad... If it wasn't for your wise words, she wouldn't have known the tales to distract the king from bloodshed"(Mahfouz 1982: 8).Therefore, Mahfouz's text highlights the ability and importance of spiritual, Sufi knowledge in supporting and shaping the mind so that it could alter human destiny, since "a pure soul can save an entire nation" (Mahfouz 1982: 8). So, it is this Sufi well from which Shahrazad drank, not Shahrazad herself that made the corrupt authority, i.e. Shahryar, rethink its world, self, and existence, as "existence itself is the most mysterious thing in existence!" (Mahfouz 1982: 4). It seems that the sultan is neither too good nor too evil, but somewhere in 
the middle. However, Mahfouz insists that this authority is entirely corrupt because its corruption has not only affected its Sultan, but also its consequent governments, which were changed six times by order of Shahryar. They are a corrupt reflection of a corrupt Sultan, as evident in the table below:

\begin{tabular}{|r|l|l|l|}
\hline & \multicolumn{1}{|c|}{ District Governor } & \multicolumn{1}{c|}{ Confidant } & \multicolumn{1}{c|}{ Police Head } \\
\hline 1 & Ali Al-Saloli & Battisha Morgan & Gamasa Al-Bolti \\
\hline 2 & Khalil Al-Hamathani & Battisha Morgan & Gamasa Al-Bolti \\
\hline 3 & Youssef Al-Taher & Hossam Al-Feky & Adnan Shoma/ Bayyomi Al-Armal \\
\hline 4 & Soleiman Al-Zeini & Al-Fadl bin Khaqan & Bayyomi Al-Armal/ Al-Mo'ein bin Sawi \\
\hline 5 & Al-Fadl bin Khaqan & Heikal-Al-Za'farani & DarwishOmran \\
\hline 6 & Abbas Al-Khaliji & Sami Shokri & Khalil Faris* (Hafez 1994: 49) \\
\hline
\end{tabular}

A closer look at this sequence of Shahryar-appointed governments in Mahfouz's narrative (governors, confidants, and police heads) reveals that corruption already holds the sultanate in its grip, since the Sultan himself is unjust. Even the pious Gamasa Al-Bolti, one of the police heads, says in a monologue: "an honest person becomes hungry in this city". He sarcastically wonders "what would happen to us if our ruler was just... Didn't the Sultan himself murder virgins and dozens of pious, righteous people?! Yet compared to other sultans, his sins are trivial indeed" (Mahfouz 1982: 37). In this monologue, he implies that the city is lost because its head/Shahryar is lost. It is not strange, then, that the body is lost too, because Shahryar had, in his oppression and corruption, murdered piousness, righteousness, and Sufi redemption (obtained through religion).Hence, Shahryar is only one of many sultans, including his predecessors and contemporaries. Mahfouz's work altered the original discourse of The Arabian Nights. Instead of a just Shahryar, he is portrayed as a tyrant, which sends a social and political message, namely that a corrupt ruler would corrupt his own government, leading to a failed state. This message is in line with the structure of Mahfouz's Nights; his narrator started by Shahryar/ the corrupt Sultan. Mahfouz disposed of Shahrazad mental faculties, though he added the religious Sufi ability of Sheikh Abdullah Al-Balkhi. The initial-three chapters ("Shahryar"/ "Shahrazad"/ The Sheikh) are a prelude to Mahfouz's text, which stresses the corruption of the ruler/ authority/ Shahryar, and that this corruption is only reversible through Sufi redemption/Sheikh Al-Balkhi.

Then the text elaborates the signs of corruption of the Shahryar-ruled Sultanate, which sinks into chaos occasionally, when the most hideous conspiracies lead to assassinations and pillages, and even the murder or the overthrow of the Sultan. This socio political-disruption takes place because the corrupt mind/ authority/ Shahryar and his governments are distant from religion. This is repeated throughout the text. In fact, this corruption and chaos are the result of the assault on the just and pious 
Sufis by Shahryar and his governments, as "the sadness and loneliness that fill the world are the result of us looking away from God" (Mahfouz 1982: 200). This separation of authority and religion is evident when Police Head DarwishOmran, the symbol and extension of the authority, wanted his son, the devilish HabazlamBazaza, to marry Zebeida, the daughter of Sheikh Al-Balkhi, the Sufi Qutb; "she is a pious, pure daughter. She's followed in her father's footsteps, and what a marvelous beauty too"(Mahfouz 1982: 195). The Sheikh politely refused, which underlines the gap between the authority/ Police Head/ the Devil on the one hand, and religion/ justice/ purity/ Sheikh Al-Balkhi/ his daughter Zebeida on the other hand. Afterwards, she gets married to Aladdin Abo Al-Shamat, the pious Muslim, son of Agar the Barber, who symbolizes the public. Having been refused by Sufis, the authority could not restore its dignity except by sinking even more into corruption and destroying all shreds of goodness; DarwishOmran, his son HabazlamBazaza, and ex-Police Head Al-Mo'ein bin Sawi steal a rare jewel from the wife of Governor Al-Fadl bin Khaqan and slip it into the pavilion of Aladdin. He is also caught with letters referring to his cooperation with the rebel Khawarij. He is then arrested and summarily tried, found guilty, and sentenced to death (Mahfouz 1982: 203-204).The trial emphasizes the corruption of the authority, its ability to devastate all who stand in its way and don't bow down to its will. Even religion and the public must obey. The text underscores the gap between the ruler and the subjects, between Shahryar and his people.

The political absurdity goes on. Aladdin Abo Al-Shamat, a symbol of justice and spiritual, Sufi faith, gets executed. Mahfouz draws a lot from The Arabian Nights, especially the original story of Aladdin Abo Al-Shamat (The Arabian Nights; Breslau 2003: 40-146) and its prominent figures, such as: Aladdin Abo Al-Shamat, Mahmoud Al-Balkhi, Zebeida Al-Oudeya, Qut Al-Qulub, and HabazlamBazaza. These characters are interwoven in the text so that they fit the modern interpretation. Aladdin bin Shams Al-Din, the son of the chief merchant of Egypt in The Arabian Nights, is turned into the son of Agar the barber, the opportunistic chatterbox (symbolizing a segment of the public in Mahfouz's world). Mahfouz also changed the character of Mahmoud Al-Balkhy, who, in the classic Nights, is a Magian disguising as a Muslim merchant. He is also a pedophile who had perverted feelings for Aladdin. In Mahfouz's work he becomes the total opposite, a Sufi Qutb, the very center of the narrative world of Arabian Nights and Days. Similarly, Zebeida Al-Oudeya, who originally marries Aladdin then passes away, becomes (in Mahfouz's work) a symbol for the continuation of Sheikh Al-Balkhi's Sufi legacy. Mahfouz's narrator, however, maintains the conspiracy mentioned in the original; Police Head Khaled and his wife Khaton plot to have Aladdin murdered so that Jasmine, the maid, can be married off to the ugly HabazlamBazaza. The latter dies of his infatuation with her after accusing Aladdin of stealing a golden lamp that belongs to the Caliph. The Arabian Nights emphasized how just the Caliph (the au- 
thority) is, as he discovers the plot and gave Aladdin a chance to remove corruption (Ahmed Qomaqim the thief). Mahfouz's world, on the other hand, focuses on the regime's corruption as it appears in everyday life.

Notably, the structure of Mahfouz's Nights is tightly constructed; the narrator moves away from the palace over the mountain, the abode of Shahryar, who symbolizes tyranny. Even Shahryar's features allude to his corruption, despite having a large beard [a sign of piety in this society], "Shahryar started his assembly with one lantern lit. His long, black her was not covered by a turban. His eyes glittered in his long face, and over his chest a large beard was outstretched" (Mahfouz 1982: 3). Afterwards, the narrative shifts to the pious Sheikh Al-Balkhi to explain that there must be a return to Sufism. The collective mind, the intellectuals and the public alike, think of Sufism as the way to overthrow or reform this political despotism. Paving the way for a moment of change that would save the city, Al-Mahini the physician says to Sheikh Al-Balkhi: "Ali Al-Salouli, our district governor, how do we save the people from his corruption?... My city, I feel sorry for you, only hypocrites thrive here. Why, my lord, is it that the worst of the lot are the ones who survive?" (Mahfouz 1982: 8-9). Later, the corruption is partly eradicated, either through murder or removal from office. The district governor Ali Al-Salouli is murdered by San'aan al-Gammali, the confidant Battisha Morgan is killed by Abdallah Al-Hammal and Gamasa Al-Bolti (the latter went on a murder spree of the regime's men, killing governor Khalil Al-Hamathany and police head Adnan Shouma). Moreover, governor Youssef Al-Taher is ousted, then his confidant Hossam Al-Feky murders him. Police head Bayyoumi Al-Armal is executed for stealing from the state treasury.

The narrative adds even more escalation. The public's dream gains momentum, along with the hope to bring down this hypocritical sultanate, which "claims to represent God's will, whereas it is mired in dirt" (Mahfouz 1982: 38). The public dreams of Utopia, as in Plato's The Republic and Al-Farabi's Virtuous City; a city where public and private life merge, where order, justice, and peace prevail, "it is as if such utopian cities and islands only exist in helpless minds that are unable to find practical solutions or reconcile the paradoxes of life" (Serkis 1979: 211). Mahfouz addresses this issue by adding characters from TheArabian Nights (Abdullah Al-Bahary [the sea dweller] and Abdallah Al-Barry [the land dweller]) (The Arabian Nights Breslau 2003: 43-83). But whereas their stories are originally related to the philosophy of death, Mahfouz makes Abdullah Al-Bahary a king of an underwater kingdom that "has become perfect, eradicated all paradoxes, and its only distress is the misery of land dwellers" (Mahfouz 1982: 87).Moreover, Mahfouz emphasizes this theme i.e. the dream for a popular movement calling for change. Ibrahim the water carrier dreams of a divine court, where he is crowned Sultan. He chooses his viziers and commanders from the hungry, barefoot masses. Every day they hold a court where, unlike real life (Mahfouz 1982: 212), justice is served, and everyone 
is pleased. When Shahryar hears of this just and popular fictional court, his good side comes to the surface. He even enforces its verdict; Al-Mo'ein bin Sawy, DarwishOmran, and HabazlamBazaza are executed for the murder of Aladdin Abo Al-Shamat (the symbol of piety, Sufi redemption, and justice). Furthermore, Al-Fadl bin Khaqan and Heikal Al-Za'farani are removed from office and their property is confiscated (Mahfouz 1982: 213).

This event marks a genuine response by the authority to the public will because the latter is stronger and more capable making changes. In The Arabian Nights, Ma'rouf the cobbler, who loved all people, especially the poor, becomes a ruler through the power of a ring demon (The Arabian Nights; Al-Hilal: 88-135). However, Mahfouz, in line with his intended message, makes the choice of the ruler a matter of public consensus rather than metaphysical or supernatural intervention. The people, therefore, choose their ruler because they can feel his compassion. In Arabian Nights and Days, the political legitimacy falls into the hand of the people. Consequently, Ma'rouf the cobbler leaves his craft to become the district governor because "He was the first to realize that the dream of a just, stable order cannot be achieved with ways whose legitimacy is not derived from, and respected by, the public will" (Hafez 1994: 52).This public legitimacy, represented by its newly elected governor, reinforces its power by forcing King Shahryar to appoint Nur al-Din as a confidant and the madman as a police head (after being renamed as "Abdullah the sane". Ma'rouf modestly says to Shahryar "my lord, I have spent my life fixing shoes. Reform runs in my blood" (Mahfouz 1982: 246). Power moves from a single ruler to the people. The King is left with no choice but to obey. He says to Dandan: "let's see what this new experience holds" (Mahfouz 1982: 246). Mahfouz hints at this ending since chapter 4, where Sindbad declares that "there is no hope for a change of scene" (Mahfouz 1982: 11). The only hope is in another world, where the river of spiritual, Sufi virtue meets the see of experience and change. Sindbad seeks new alternatives because he distrusts the current regime, which had burdened him and many of his people until he could no longer withstand it. He insists on leaving his homeland to an unknown destination. He boards a ship (not unlike Noah's Ark) to survive the corruption in his homeland, raging like a tornado.

At the end of the novel, Mahfouz uses Sindbad wise voice to narrate a founding constitution for any just state that takes responsibility for its people. These principles include: Using all the senses and reason God has blessed Man with, vigilance, moderation, Liberty from obsolete traditions, freedom, and walking in God's guiding light.

This constitution, which reconciles reason and religion, made the regime reconsider its actions and repent its decade-long bloodshed, "it is time for me to listen to the call of redemption, the call of wisdom" (Mahfouz 1982: 258). The gates of the city are open for virtue. The future is left in the hands of the son (the young generation) to determine his own future and fulfil his destiny. Mahfouz here draws 
inspiration from the classic 'Nights'; he mentions five out of seven of the originalSindbad journeys he undertook after he spent all his inheritance from his rich merchant father. Sindbad recounts the events to the poor porter who has many children so that the latter can learn from learn from Sindbad's mistakes. He alludes to his second, third, fourth, fifth, and seventh journey (The Arabian Nights - Breslau 2003: vol. 3-267-394 \& vol. 4-4-133).

Mahfouz's text continues its 'treacherous' intertextual connection to The Arabian Nights to serve its own purpose. It blends the two 'Sindbads' in the original, the rich one and the poor one, into a single character. Mahfouz's Sindbad starts his life as a poor porter, then ends up as a sage, thus reaffirming Mahfouz's moral of seeking a just, democratic state.

\section{Magical-Realism and the Balance of Fate}

The concept of "Magical-Realism" was coined in 1925 by the German art critic Franz Roh in an essay titled "Magical-Realism: Post-Expressionism" (Zamora and B. Faris 1995: 15-31), later included in an edited book titled "Magical-Realism: Theory, History, and Community". In this essay, he "indicate[s] the demise of expressionism, magical realism grew to become an important feature of the Boom literature in the 1960s in Latin America (particularly in Gabriel García Márquez's One Hundred Years of Solitude of 1967), until it became, in the 1990s, in the words of Homi Bhabha 'the literary language of the emergent post-colonial-world'." (M. Hart 2005: 1).

This does not mean that such a mythical awareness of the world was limited to Latin America; Magical Realism is a global literary phenomenon that has been featured in the literature of many nations in many eras. For example, it is found in Arabic, Chinese, Japanese, Spanish, German, and French literary traditions.

It is noteworthy that Magical Realism is a blend on fantasy and realism, in which "magic penetrates the fabric of reality, and reality enhances the magic world" (M. Hart 2005: 4). There is a dialectic relationship between the natural and the supernatural, reality and unreality, the seen and the unseen. In the words of Roger Caillois: "The fantastic is an abandonment of, or a crack in, the status quo. It is an assault by the unacceptable on the essence of the unchangeable legitimacy of everyday life" (Todorov 1994: 45); it is some sort of constant movement between fantasy and reality, according to Todorov.

This magical/ fantastical aspect in different literary traditions was not only derived from the supernatural elements in local myths and religions, but also from older literary works by means of intertextuality. In fact, this is what English writer Anthony Burgess (1917-1993) did; he drew inspiration from texts preceding Western realism (chin Ouyang 2005: 17). 
Such writing, so filled with fantasy, is a creative adventure. It usually aims at discussing taboos through symbols. It is able to address the issues of everyday life and to criticize the social, political and religious aspects of the status quo. Unlike realism with its strict molds, Magical Realism can avoid any direct confrontation with the law, taboos, and censorship authorities.

All of this is embodied in Mahfouz's Arabian Nights and Days; demons and supernatural events play a major role within the novel's narrative. They cause developments and transformations in the city, driving it from silent submission to action and change. As a result, the socio-political balance of the city (i.e. reason/ religion/ freedom) is restored thanks to a strong public will. Mahfouz, by including these supernatural elements, did not stray far from The Arabian Nights, where these elements had an active, essential role since the first line of the frame story (The Arabian Nights 2003: 12-15); if Shahryar and his brother Shah Zaman hadn't been seduced by the Jinni's wife, whom he had abducted on her wedding day, Shahryar would not have returned to his throne. His kingdom, and consequently Shahrazad's world, would have been lost.

Mahfouz, in resorting to such supernatural-elements, depends on dichotomies: good vs. evil, faith vs. blasphemy, the regime vs. the people, tyranny vs. freedom. This dichotomy is exemplified by two types of demons, the faithful ones (Qomqam and Singam) and the blasphemous ones (Sakharbot and Zrimbaha).

The good supernatural-beings 'Qomqam' and 'Singam' symbolize the human conscience that encourages the obedient people to resist tyranny. The regime, on the other hand, does not shy away from using any power, even if it was supernatural, to maintain its corrupt authority. The district governor Ali Al-Salouli uses black magic to enslave the faithful demon Qomqam, who says that "he makes me do things that my conscience cannot tolerate" (Mahfouz 1982: 15).

In order not to make redemption a purely supernatural event, Qomqam chooses the merchant San'aan Al-Gammaly and police head Gamasa Al-Bolti as agents who would rid the city of injustice. Mahfouz believes that reform must start from the top. Therefore, Qomqam uses the merchant San'aan Al-Gammaly to get rid of the district governor Ali Al-Salouli. However, once Qomqam is released from the black magic that binds him, he abandons the former (leaving him to be executed) because he wants him to become a martyr:

"- be a hero, San'aan. It is your destiny.

- I don't want to be a hero!

- Your flaw, San'aan, is that you don't think like a human being does" (Mahfouz 1982: 34).

The elite as a class can neither redeem nor reform society. They deserve to be beheaded for straying from the right path and depriving the young generation of happiness. For example, San'aan Al-Gammaly murdered an innocent girl after he had raped her. 
Accordingly, change requires a hero, a savior, who can lead humanity to a greater destiny. This role is fulfilled by Gamasa Al-Bolty. He hangs between good and evil, between obedience to the authority and faith in the teachings of Sheikh Al-Balkhi, though he has what it takes to be a savior. That is why Mahfouz spares him. After he is sentenced to death for freeing the Shia and the Khawarij rebels and for murdering Prince Khalil Al-Hamathany, the faithful demon Singam releases him, explaining that "you are a live; they only killed an illusion of my making" (Mahfouz 1982: 36). The text, therefore, supports 'transformative redemption'; Gamasy Al-Bolti is transformed into Abdallah Al-Hammal [the porter], who murders the confidant Battisha Morgan and the police head Adnan Shouma. Then he is transformed into the fisherman Abdallah Al-Barry, a madman, and a wise man. Later he is appointed police head once again in the government of Ma'rouf the shoemaker. Thus, Al-Bolti helps in the triumph of justice over tyranny in Shahryar's city.

The Supernatural is a prominent device in Mahfouz's text. It reveals how corrupt the regime, in its entirety, truly is. The ruling class did not care for the interests of the people until the entire regime collapses. The Evil demons Zimbaha and Sakharbot change their forms. Zrimbaha transforms herself into an alluring lady called 'Anis Al-Jalis' who hosts night parties at the brothel by the weapon market, whereas Sakharbot transforms himself into her slave. Together they try to lure the regime's men into a trap, including Shahryar himself, Al-Mo'ein bin Sawi, Al-Fadl bin Khaqan, Soleiman Al-Zeiny, Nour El Din, Dandan. The said trap will make "the people in the market see their Sultan and statesmen completely naked!" (Mahfouz 1982: 171). by being humiliated in this way, they can once again feel human vulnerability and regain their long-lost capacity to feel shame.

However, Mahfouz spared Shahryar's regime this scandal, not to cover-up for such corrupt officials, but to save the nation and the people from serious consequences. A regime is temporary, but the nation cannot be reclaimed if it descends into chaos. That's why Abdallah the madman tells his friend Abdallah Al-Bahary: "I feared that morning would come, and the subjects would find no Sultan, governor, confidant, or police head. It would mean that the strongest evil person would claim the throne" (Mahfouz 1982: 174). Mahfouz prioritizes the public interest by sparing the dignity of the ruling class, thus maintaining the nation's stability.

In this regard, Mahfouz's text interacts with The Arabian Nights by borrowing characters such as 'Anis Al-Jalis', 'Al-Mo'ein bin Sawi', 'Al-Fadl bin Khaqan', and 'Soleiman Al-Zeiny. He draws inspiration from the tale of "Nur al-Din Ali and the damsel Anis Al-Jalis" (The Arabian Nights 2003: 67-166), in which Nur al-Din falls in love with the pretty damsel Anis Al-Jalis. As in many happy tales, the lovers are reunited by order of Caliph Harun al-Rashid. Mahfouz, however, turns the damsel into an evil demon. Similarly, the king of Basra Mohammed bin Soleiman Al-Zeiny and his two viziers, the foolish al-Mo'ein bin Sawi and the generous al-Fadl bin Khaqan, are all turned into corrupt officials in Shahryar's regime. This intertextual interaction benefits Mahfouz's novel by advancing the plot and stressing Shahryar's corruption. 
In Arabian Nights and Days, what can be called 'dark fantasy' i.e. Zrimbaha and Sakharbot does not only humiliate the officials by stripping them naked, but it also has a role in changing the fate of some characters. DoniaZad, Shahrazad's sister, is wed to a demon, disguised as the perfume merchant Nur al-din. The wedding is consummated. The narrative emphasizes Shahryar's dominance; it is him who approved of this false wedding. As a result, DoniaZad became a cause of worry and stress for her family, whereas in The Arabian Nights she had an active role in saving the life of Shahrazad and all women, "O, sister. If you are still awake, tell us some of your fine tales to ease our insomnia. Your tales are what saved me and the whole world of a dire calamity. They awakened the king from his slumber. Shahrazad responded, 'I shall tell you some'...” (The Arabian Nights 2003: 31).

This false wedding indicates that Shahryar's authority and security forces have been infiltrated by supernatural-powers that managed to reach his royal-palace, where DoniaZad (the symbol of virtue and purity) and her sister Shahrazad live.

Not only did these supernatural-powers infiltrate the Sultan's palace, they also infiltrated the religious movements i.e. the Shia and Khawarij rebels; the evil demons Sakharbot and Zrimbaha give the invisibility cap to FadelSan'aan, who was then distracted from his life in resistance to live a life of absurdity. He steals from the butcher, commits trivial, meaningless acts, kills Shawir the prison guard and Moharram the watermelon merchant, rapes and murders Qut al-Qulub, the wife of Soleimam al-Zeiny, and escapes prison after being arrested (Mahfouz 1982: 219-225). Hence, "Fadel" [whose name means 'virtuous'] betrays his own name and his people. Instead of resisting Shahryar's authority, he secretly went after his personal interests, which eventually lead to his downfall and execution. This is the moral of Mahfouz's work: Collective action, rather than individualism, is the path towards a public will with the ability to change the status quo.

Mahfouz is inspired here by the "Tale of Hassan al-Basri" (The Arabian Nights 2003: 136-179, Al-Qalamawy 1943: 141-142) in The Arabian Nights, in which the protagonist uses the cap of invisibility to save his wife and his two sons, Nasser and Mansour, from his sister-in-law, the evil queen Nur al-Huda. He tricks the two sons of a dead magician in order to take this cap, along with an ornamented brass staff. In the original tale, the invisibility cap is used for a noble purpose, i. e. eliminating the evil Nur al-Huda. Mahfouz, on the other hand employs it to reveal the shallow thinking of the Shia and Khawarij rebels, which eventually leads them to a tragic downfall.

When one of the rebels, FadelSan'aan, demands justice at his trial, the angel of death (disguised as the auctioneer Sahlool) replies in a neutral tone "Allah does whatever he wills". The reply implies his acceptance of the trial, since the rebels strayed from God's path, which can be summed up as the path of "mind and soul" or "reason and religion. The rebel sank into the absurdity of Shahryar's city, therefore they, like the corrupt officials who strayed from the path of justice. must be put to 
trial. It is as if the moral here is to strike a fine balance between the material and spiritual life. This is the path to fulfill human destiny; the king says: "whoever has a dream, has a future".

\section{The Symbolism of the Setting}

The setting plays a central role in shaping the narrative structure of Mahfouz's fictional world. It is a window through which the narrator can view everyday life, the changes in the civilization, and the burdens of people; a window through which he anticipates the fate of humanity with absurd existentialism interwoven with Sufism. The setting of Mahfouz's works becomes the center of the whole world, a symbol of existence itself, which is clear in novels like: Cairo Modern, Khan Al-Khalili, Midaq Alley, The Beginning and the End, Palace Walk, The Palace of Desire, Sugar Street, The Thief and the Dogs, Adrift on the Nile, Fountain and Tomb, The Harafish, among others. In all these works, the narrator focuses on the setting, the alleys, lanes and coffee shops of Fatimid Cairo. He sheds light on social, political, and cultural-changes in Egyptian societies.

However, it is the "coffee shop" that gets the most attention in Mahfouz's narrative, since "the coffee shop plays an essential role in my novels, and in all our lives. We didn't have clubs back then. The coffee shop was the center of friendship" (Al-Gheitany 1980, 88). These places are a source for narration and memories, for venting about concerns, whether personal or political.

Mahfouz's vision for the setting affected its multiple connotations, especially in relation to the structure of the narrative of Arabian Nights and Days. His narrator is no longer concerned with Shahrazad's royal bed chamber, nor her fight for her own survival. Instead, Mahfouz, in his artistic realism, shifted the focus to an entirely different world i.e. "The Coffee Shop of Princes"; it is a symbol for the country, for Shahryar's people that suffer from social and political absurdity. It symbolizes the different segments of society: the elite and the public, the rich and the poor, the intellectuals and the illiterate. It is a coffee shop/ nation whose "entrance is on the main street, and its windows are on side alleyways [inhabited by the poor]". But despite this symbolic homogeny, the people are absent-minded because they consume "the best crack and hashish", to the extent that the people can only hope for Shahryar's pardon, "that night, fear has loosened their grip on them. Every father of a beautiful virgin calmed down. They were promised a serene sleep without any looming ghosts" (Mahfouz 1982: 10).

In spite of such absentmindedness (crack and hashish), which symbolizes public will's weakness against the authority/ Shahryar, Mahfouz's text makes this public will (i.e. The Coffee Shop of Princes/ the nation/ the people/ the city/ the alley) triumphant at the end. The narrator notes its increasing power as events unfold until the people take their own decision and choose their new ruler (Maa'rof the cobbler). Hence, the coffee shop/ the people/ the nation remain, and it is Shahryar who departs. 
Notably, Mahfouz's narrator provides a detailed description of "The Coffee Shop of Princes" (Mahfouz 1982: 10) (a symbol for the nation/ the people) to highlight the absurdity of this society under the rule of Shahryar, who lives in "a palace over the mountain" (Mahfouz 1982: 7), isolated from his people. He is the one who pardons, whereas the absent-minded people are only passive recipients. Accordingly, the setting is dichotomous; on the on hand we see the coffee shop/ the people/ the nation/ the city/ the alley/ the public will/ justice, and on the other hand we find the palace above the mountain/ beheading/ the court/ prisons/ the king/ tyranny. The narrator does not describe the royal palace, but intricately portrays the coffee ship. This reaffirms the shift of power from the despotic ruler/ Shahryar/ the palace to the people/ the public will/ the coffee shop/ the city. It is this condition that represents the ending of the narrative in Arabian Nights and Days.

This discrepancy in the text, between the palace/ the authority on the one hand, and The Coffee Shop of Princes/ the people on the other hand, would not have led to justice without Sufism/ Religion, symbolized by the home of the Sufi QutbAbdallah Al-Balkhi, as "he lives in a simple house in the old district... Beyond the empty space by the river, close to a green stretch extending into the river" (Mahfouz 1982: 7). This simple house bears the mark of genuine knowledge that doesn't lust after power. All its owner wants is to live on the green stretch extending into the river. It is there that he can wash himself from the sins of this regime and return to the city/ justice/ goodness.

\section{Conclusions}

Mahfouz's Arabian Nights and Days manage to interact with the classic Arabian Nights in terms of its frame story and other tales such as those of Sindbad, Abdallah Al-Barry, Abdallah Al-Bahary, Maa'rouf the cobbler, the cap of invisibility, among others. This interaction enriched Mahfouz's text and its modern connotations, such as shedding light on the social and political absurdity. Such an effect was demonstrated by changing the characters, metaphysical events, and setting of the classical text. Furthermore, the intertextual connections underline how The Arabian Nights, as a classical-text, is still relevant today despite all creative and critical-developments.

\section{Bibliography}

Abo Al-Hussein, H. 1994 "Shahrazad and the development of the French novel from Classicism to Symbolism”. Fusul Journal, the General Egyptian Book Authority, Egypt. vol. 13.2. summer. 268. 275-276. [Original title: هيام أبو الحسين- شهرز اد وتطور الرواية الفرنسية من الكلاسيكية إلى الرمزيةـ فصول- الهيئة

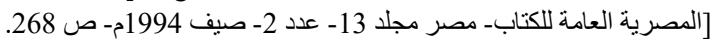

Al-Gheitany,Gamal. 1980. "Naguib Mahfouz Remembers", Al-Maseera Publishing House - ed. 1. $54-42-88$. 


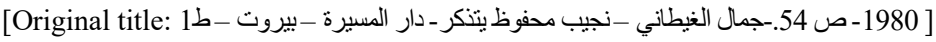

Al-Musawi, Muhsin J. 2004."The "mansion" and The Rubish Mounds: "The Thousand and one Nights in popular Arabic tradition, Journal-of Arabic literature, vol. 35, No. 3. 351-352.

Al-Qalamawy, Saheir. 1943.“Alf LailawaLaila (One Thousand and One Nights”. Egypt, Al-Ma'aaref publishing house. 2-141-142. [Original title: - سهير القماوى- ألف ليلة وليلة- مطبعة المعارف ومكتبتها بمصر-"Al .21943 ] 2 [

Al-Zamarli,Fawzi. 2002. "The Poetics of the Arabic Novel: A Study into the Forms and Meanings of Arabic Novels”, Tunisia, University Publishing Center. 144. [Original title: فوزي الزمرلي- شعرية الرواية

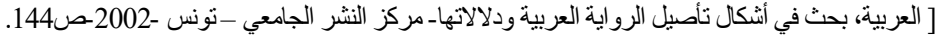

Hafez, Sabri. Summer 1994. "The Dialectic of the Complex Narrative Structure in the 'Nights' of

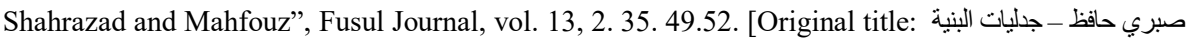

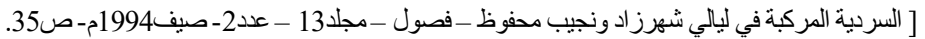

Hawthorn, Jereny. 1992. "A Glossary of Contemporary literary theory", Distributed in the USA by Rutledge, Chapman and Hall, Inc. 29 west $35^{\text {th }}$ street, New york, NY 10001.

Irwin, Robert. 1994 "The Arabian Nights: A Companion". Allen Lane- thePenguin press,New York, USA. $42-43$.

Knipp, C. 1974. "The Arabian Nights" in England: Galland's translation and its successors-Journal-of Arabic Literature, vol. 5, 48. Fahndrich, Harmut. 2000, "Viewing" The Orient" and Translation Its literature in the shadow of the Arabian Nights, Yearbook of Comparative and General-literature.48, Indiana University, Bloomington, Indiana.98.

Mahfouz, Naguib. 1982. "Arabian Nights and Days”, Egypt library, 3-4-6-7-8-9-10-11-15-34-36-37-38-

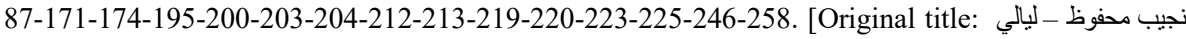

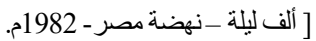

Mahfouz,Naguib, 1994. "The Arabian Nights Encapsulated the Oriental-Civilization", Interviewed by: Hussein Hammouda - Fusoul Journal, The General-Egyptian Book authority, vol. B - 2. 378-380.

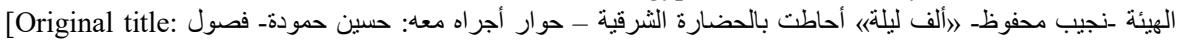

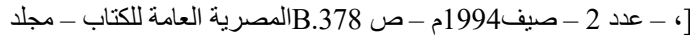

Serkis, Ihsan. January 1979. "Duality in the Arabian Nights”,Beirut, Al-Tali'a Publishing House, ed. 1. 211. [Original title: إحسان سركيس- الثنائية في ألف ليلة وليلة - دار الطليعة - بيروت - ط1 يناير 1979- ص211 ]

Zamora,Lois Parkinson and Faris, Wendy B. 1995. "Magic realism: post-Expressionism, in MagicalRealism, Theory, History, Community”, (Durham, NC: Duke University press), 15-31.

Hart, Stephen M. and wen-chin Ouyang. 2005. "A Companion to Magical-Realism, Tamesis, wood bride, NY, USA. 1-4-17.

The Arabian Nights and Days. (n.d)."Riwayat Al-Hilal-(Al-Hilal-Novels, a monthly journal-of world

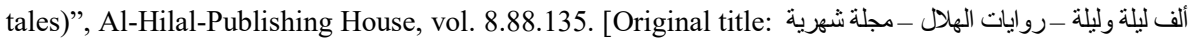

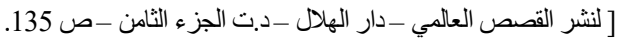

The Arabian Nights. 2003. Breslau Edition - The Egyptian National-Library and Archives, vol.1-3-4.

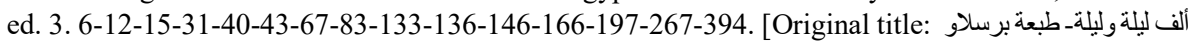

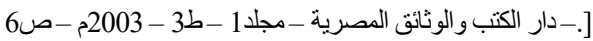

Todorov, Tzvetan. 1994. "Introduction à la littératurefantastique - translated into Arabic by: Al-SeddiqboAllam, reviewed by: Mohammed Birada - Foreign Cultural-Studies - Sharqiyyat Pub-

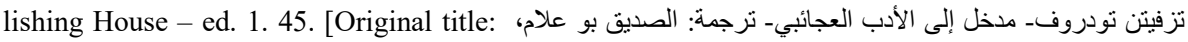

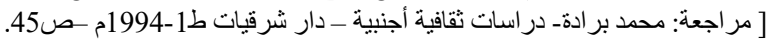

Uspenskij, Boris. 1999. "A Poetics of Composition: The Structure of the Artistic Text and Typology of a Compositional-Form", Translated into Arabic by: Said Al-Ghanimy and NasirHallawi, Egypt, the National Center for Translation, the Supreme Council of Culture. 149. [Original title: - بوريس أوسبنسكي شعرية التأليف، بنية النص الفني وأنماط الثنكل التاليفي- ترجمة: سعيد الغانمي، وناصر حلاويـ المشروع القومي للتزجمة - المجلس

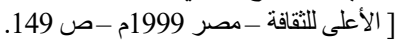


